\title{
Pembelajaran Menggunakan Metode Inkuiri Terbimbing dan Picture and Picture Untuk Meningkatkan Hasil Belajar IPS Siswa SD
}

\author{
Marlina*, Rita Retnowati**, Nurlaela Mei Tienje** \\ * Mahasiswa Program Studi Administrasi Pendidikan, Program Pascasarjana \\ ** Staf Dosen Program Studi Administrasi Pendidikan, Program Pascasarjana \\ Universitas Pakuan \\ Bogor, Indonesia
}

Diterima: 17 November 2015. Disetujui: 23 Desember 2015. Dipublikasikan: Januari 2016

\begin{abstract}
Abstrak
Pendidikan merupakan investasi masa depan yang menjadi pilihan utama bagi setiap keluarga dan bangsa terutama bangsa yang sedang berkembang. Pendidikan merupakan salah satu unsur yang terpenting dalam perkembangan manusia karena dengan pendidikan akan dihasilkan manusia-manusia yang berkualitas. Sekolah merupakan suatu lembaga pendidikan yang diharapkan mampu menghasilkan manusia yang berkualitas. Dalam hal ini, sekolah tidak hanya berperan dalam edukasi yaitu proses pendidikan yang menekankan pada kegiatan pendidik, akan tetapi di dalam sekolah juga terjadi proses sosialisasi, proses perubahan tingkah laku pada siswa. Penelitian dilaksanakan melalui siklus yang berdaur ulang yang berulang secara berkesinambungan. Penelitian dilaksanakan dalam dua siklus, tiap siklus terdiri dari dua tindakan pada setiap siklus terdiri dari 4 tahapan, yakni tahap perencanaan, pelaksanaan tindakan, pengamatan (observasi) serta analisis dan refleksi. Hasil penelitian memperlihatkan perubahan secara signifikan dilihat dari peningkatan hasil belajar baik kognitif, afektif, dan psikomotor nilai kognitif pada siklus pertama mencapai klasikal sebesar 44\%. pada siklus kedua pencapaian klasikal sebesar 84 \%. Nilai rata-rata kelas pada siklus pertama adalah 69 pada siklus kedua nilai rata-rata sebesar 84.36. Nilai afektif pada siklus pertama mencapai rata-rata skor 77 (kurang). Pada siklus kedua mencapai rata-rata skor 80.36 (B). Nilai psikomotor pada siklus pertama mencapai rata-rata skor 14 (B). Pada siklus kedua mencapai ratarata skor 19.12 (A). Begitupula antusiasme belajar siswa pada siklus pertama On Task $87 \%$ off Task $13 \%$. Pada siklus kedua mencapai On Task 98 \% Off Task $2 \%$. Berdasarkan hasil temuan di atas dapat disimpulkan bahwa metode inkuiri terbimbing dan Picture and Picture dalam pembelajaran IPS dapat meningkatkan hasil belajar siswa.
\end{abstract}

(C) 2016 Program Pascasarjana Universitas Pakuan

KATA KUNCI: Hasil Belajar IPS, Inkuiri Terbimbing dan Picture and Picture .

\section{PENDAHULUAN}

Pembelajaran merupakan suatu proses suatu sistem yang melibatkan berbagai komponen antara lain pendidik, peserta didik, materi, sumber belajar, media pembelajaran, metode, pengorganisasian, informasi dan langkah-langkah sistematik. Guru adalah komponen dalam pembelajaran dan salah satu unsur manusia dalam proses pendidikan. Dalam proses pendidikan guru di sekolah memegang peran ganda yaitu sebagai pengajar dan pendidik. Keberhasilan 
proses pembelajaran tidak dapat lepas dari peran guru. Guru dituntut untuk melaksanakan tugasnya secara profesional.

Guru yang profesional haruslah mampu mengaplikasikan berbagai teori belajar dalam pengajaran, mampu memilih dan menerapkan metode pengajaran yang efektif dan efisien, mampu melibatkan siswa berpartisipasi aktif dan mampu menciptakan suasana belajar yang menunjang tercapainya tujuan pendidikan.

Pendidikan dasar memegang peranan sangat penting bagi jenjang pendidikan selanjutnya. Pendidikan pada level sekolah dasar harus berhasil mencapai tujuan pendidikan yang telah ditetapkan dengan hasil belajar yang lebih meningkat. Semua itu bila pengajaran tersebut mampu mengubah peserta didik dengan meningkatkan kemampuan dan prestasinya dan itu dapat dilihat dari hasil yang telah dicapainya, untuk itu seorang guru perlu meningkatkan mutu pembelajaran dimulai dari rancangan pembelajaran yang baik dengan memperhatikan tujuan, karakteristik siswa, metode, materi yang diajarkan dan sumber belajar yang tersedia.

Untuk mencapai tujuan yang telah ditetapkan itu, maka banyak komponen yang harus dipenuhi. Mulai dari kurikulum yang baik, tenaga pengajar yang kompeten dan seterusnya. Salah satu hal yang krusial patut dipahami adalah karakteristik siswa atau peserta didik. Demikian halnya dalam pembelajaran Ilmu Pengetahuan Sosial, pengembangan karakteristik peserta didik akan terbentuk. Melalui mata pelajaran IPS peserta didik dapat menjadi warga Negara Indonesia yang demokratis dan bertanggung jawab.

Melalui pelajaran IPS juga dapat membangkitkan kesadaran bahwa akan berhadapan dengan kehidupan yang penuh tantangan atau dengan kata lain IPS mendorong kepekaan peserta didik terhadap hidup dan kehidupan sosial. Diharapkan dalam pembelajaran IPS akan muncul tingkah laku dan sikap siswa yang selalu dilandasi dengan tanggung jawab terhadap dirinya sendiri maupun terhadap lingkungannya.

Dalam pelajaran IPS, terdapat berbagai perpaduan dari konsep ilmu-ilmu sosial, misalnya: sejarah, geografi, budaya, ekonomi dan sebagainya. Penanaman nilai dan sikap pada pelajaran IPS hendaknya dipersiapkan dan dirancang berkesinambungan dengan penekanan pada setiap jenjang yang berbeda. Semakin tinggi tingkat jenjangnya akan semakin besar pula tanggung jawab dan pemahamannya.

Dengan demikian IPS diharapkan dapat membangkitkan kesadaran bahwa akan berhadapan dengan kehidupan yang penuh tantangan atau dengan kata lain IPS mendorong kepekaan peserta didik terhadap hidup dan kehidupan.

Pembelajaran IPS di kelas V SD Muhammadiyah dirasakan kurang bermakna. Hal ini terlihat dari aktivitas siswa baik ketika siswa sedang mengikuti pembelajaran maupun setelah kegiatan pembelajaran berlangsung. Siswa cenderung tidak memahami konsep-konsep yang berkaitan dengan kehidupan masyarakat dan lingkungannya seperti apa yang menjadi tujuan dalam pembelajaran IPS. Pembelajaran IPS pada tingkat pendidikan dasar memiliki berbagai masalah. Ada dua masalah besar yaitu: Pertama, sampai sekarang pelajaran IPS di sekolah masih dianggap pelajaran yang membosankan, terasa sukar, dan tidak menarik, sehingga mengakibatkan hasil belajar rendah. Kedua, IPS merupakan ilmu yang sangat berguna bagi kehidupan manusia, tetapi banyak yang 
belum bisa mendapatkan manfaat IPS dalam kehidupan sehari-hari.

Hal ini terjadi karena kurangnya kualitas kegiatan belajar mengajar IPS yang secara umum masih dilaksanakan secara konvensional, klasikal dan strategi pembelajaran masih berpusat pada guru (teacher center) dan tidak menyenangkan, sehingga dapat menyebabkan siswa kurang terlibat dalam pembelajaran. Peserta didik umumnya hanya catat, diam duduk, dengar dan hapal. Pembelajaran ini mengakibatkan peserta didik kurang berpartisipasi dalam kegiatan belajar, karena mereka cepat bosan, dan malas belajar. Gambaran permasalahan di atas menunjukkan bahwa pembelajaran IPS perlu diperbaiki guna meningkatkan pemahaman konsep siswa. Untuk itu diperlukan solusi yang tepat untuk mengatasi masalah tersebut sehingga mendorong peneliti untuk mengkaji inovasi pengajaran dan pembelajaran untuk memacu keberhasilan siswa dalam hasil belajar IPS pada siswa kelas $\mathrm{V}$ di SD Muhammadiyah Kecamatan Bogor Selatan Kota Bogor.

Diantara pembelajaran yang akan dikaji pada penelitian ini adalah materi tentang mendeskrIPSikan kerajaaan dan peninggalan masa Hindu-Budha dan Islam di Indonesia dengan metode inkuiri terbimbing dan Picture and Picture yang akan dilaksanakan di Sekolah Dasar, karena siswa Sekolah Dasar merupakan anak yang berada pada tahapan berfikir secara konkret sehingga pembelajaran ini dapat ditunjang dengan media pembelajaran. Sebagian besar guru memberikan materi berupa konsep-konsep baru, tanpa terlebih dahulu mengaitkan dengan konsep-konsep yang telah mereka miliki sebelumnya. Hal ini juga dipadukan dengan pembelajaran IPS yang dominan monoton dan tidak menarik sehingga menurut siswa untuk berpikir keras untuk memahami materi dan mengakibatkan hasil belajar yang tidak memuaskan.

Permasalahan di atas terjadi pada peserta didik kelas $V$ di SD Muhammadiyah Kecamatan Bogor Selatan Kota Bogor, setelah dilakukan pengamatan maka, faktor penyebab rendahnya hasil belajar IPS dalam mendeskrIPSikan kerajaan dan peninggalan masa Hindu-Budha dan Islam di Indonesia kelas $\mathrm{V}$ karena siswa kesulitan dalam menghapal, guru dalam mengajar masih menggunakan metode ceramah saja, dan peserta didik kurang antusias dalam menghadapi pelajaran IPS, suasana di dalam kelas pun sangat gaduh, terbukti dengan permasalahan-permasalahan tersebut hasil Ulangan Akhir Semester Genap Tahun Pelajaran 2014/2015 pada pelajaran IPS kelas 5 relatif rendah, dan masih menunjukkan hasil di bawah standar ketuntasan minimal (KKM). Adapun Kriteria Ketuntasan Minimal (KKM) mata pelajaran IPS yang telah ditetapkan di SD Muhammadiyah yaitu 75 .

Pada Standar Kompetensi perjalanan bangsa Indonesia pada masa Hindu-Buddha, Islam, sampai masa kemerdekaan, dengan Kompetensi Dasar kemampuan mendeskrIPSikan kerajaan dan peninggalan masa Hindu-Buddha dan Islam di Indonesia di kelas 5 SD Muhammadiyah selalu mengalami kesulitan dilihat dari dokumen guru tentang nilai KKM (Kriteria Ketuntasan Minimal) yaitu kriteria paling rendah untuk menyatakan peserta didik dalam mencapai ketuntasan belajar. Dapat dikutip dari laporan nilai hasil belajar bahwa hasil belajar IPS pada Tahun Pelajaran 2012/2013 adalah 60 dengan KKM 62, Tahun Pelajaran 2013/2014 adalah 61 dengan KKM 62, dan pada Tahun Pelajaran 2014/2015 adalah 63 dengan KKM 65. 
Adanya kondisi tersebut memunculkan suasana belajar yang kurang menyenangkan. Kurangnya motivasi belajar dan pelajarannya dianggap sulit, yang mengakibatkan siswa didalam kelas sering ngobrol dengan sesama temannya. Siswa belum tergugah hatinya untuk menciptakan suasana kelas yang kondusif, dan penghargaan antar teman kurang. Menghadapi tingkah laku, sikap, emosi dan respon siswa seperti itu guru dituntut kesabaran yang tinggi secara kontinyu memberikan motivasi dan melibatkan siswa dalam proses pembelajarannya.

Untuk mengatasi masalah di atas dalam upaya meningkatkan hasil belajar siswa agar tercapai nilai minimal sama dengan KKM sehingga mampu meningkatkan hasil belajar IPS, perlu diadakan Penelitian Tindakan Kelas (PTK) Metode Pembelajaran dalam meningkatkan Hasil Belajar IPS Kelas V SD Muhammadiyah.

Guru yang baik akan merasa bertanggung jawab untuk memilih metode paling tepat dengan media kelengkapan, media pengajaran dalam upaya membantu siswa belajar, sehingga hasil belajar dapat berjalan untuk mencapai tujuan pengajaran. Siswa akan mudah menerima pelajaran dengan mengaktifkan seluruh panca indera, sehingga menjadikan sebagai suatu pengalaman yang tidak mudah dilupakan.

Berdasarkan uraian di atas bahwa diduga pembelajaran masih bersifat konvensional dan siswa hanya sebagai penerima yang pasif sedangkan siswa usia 10-11 tahun dimana mereka masih suka bermain, maka peneliti akan memberikan metode pengajaran yang menyenangkan untuk pelajaran IPS kelas V SD, sehingga siswa dapat meningkatkan hasil belajarnya. Suatu metode yang mana siswa berperan aktif untuk menemukan suatu informasi dengan sendirinya sehingga siswa lebih paham dan mudah untuk menyampaikannya, hal ini cocok dengan metode inkuiri terbimbing dimana siswa berperan sebagai penemuan atau peneliti suatu masalah atau informasi dengan begitu siswa tidak ada kesempatan untuk mengobrol atau membuat gaduh di kelas. Pemilihan kedua adalah Picture and Picture yang kedua-duanya menekankan keaktifan siswa sehingga semua siswa ikut terlibat dan siswa tidak mempunyai kesulitan lagi dalam mempelajari materi IPS yang banyak dan padat, tidak mudah lupa sehingga diharapkan hasil belajar meningkat.

Berdasarkan latar belakang masalah yang telah diuraikan, maka rumusan masalah adalah sebagai berikut:

1. Apakah pengelolaan pembelajaran dalam menerapkan metode Inkuiri Terbimbing dan Picture and Picture dapat meningkatkan hasil belajar pada pelajaran IPS kelas $\mathrm{V}$ SD?

2. Bagaimana pengelolaan pembelajaran menggunakan metode Inkuiri Terbimbing dan Picture and Picture untuk meningkatkan hasil belajar pada pelajaran IPS kelas V SD?

\section{METODE}

Penelitian ini dilakukan terhadap siswa kelas V SD Muhammadiyah Kecamatan Bogor Selatan Kota Bogor pada mata pelajaran IPS di semester ganjil tahun pelajaran 2015/2016. Penelitian dilakukan secara kolaboratif oleh 4 orang guru, 2 orang guru sebagai observer, 1 orang guru sebagai model, dan 1 orang guru sebagai kameramen. Jumlah siswa kelas $\mathrm{V}$ sebanyak 25 siswa yang terdiri dari 12 siswa perempuan dan 13 siswa laki-laki. Sedangkan obyek penelitiannya adalah keseluruhan proses pembelajaran dengan menerapkan 
Metode Pembelajaran Inkuiri Terbimbing dan Picture and Picture dalam mata pelajaran IPS di SD Muhammadiyah Kecamatan Bogor Selatan Kota Bogor. Metodologi yang digunakan adalah penelitian tindakan kelas (PTK) atau Action Research. Metode ini digunakan untuk melakukan sebagai tindakan yang bertujuan untuk memperbaiki dan menyempurnakan proses pembelajaran di kelas. PTK bersifat kolaboratif, oleh karena itu guru mata pelajaran IPS akan dilibatkan untuk membantu mengobservasi dan merumuskan persoalan yang perlu dicari solusinya dan diperbaiki.

Proses dalam PTK merupakan siklus yang dapat dilakukan berulang-ulang. Dalam satu siklus penelitian, ada empat langkah yang harus dilakukan, yaitu perencanaan (planning), pelaksanaan (acting), observasi (observation), dan refleksi (reflection). Jumlah siklus dalam satu penelitian akan tergantung pada kriteria keberhasilan yang direncanakan oleh peneliti. Jika hasil akhir setelah dilakukan tindakan menunjukkan hasil yang diharapkan, maka siklus dapat dihentikan dan sebaliknya bila di akhir tindakan belum menunjukkan hasil yang diharapkan maka dapat dilanjutkan ke siklus berikutnya.

\section{HASIL DAN PEMBAHASAN}

Pelaksanaan pembelajaran pada siklus 1 berdasarkan langkah-langkah yang sesuai dengan rpp. Sesuai dengan pernyataan bahwa pengetahuan dan keterampilan yang diperoleh siswa diharapkan bukan hasil mengingat seperangkat fakta-fakta, tetapi hasil dari menemukan sendiri. Picture and Picture merupakan strategi pembelajaran yang menggunakan gambar sebagai media pembelajaran, dimana gambar yang diberikan pada siswa harus dipasangkan atau diurutkan secara logis.
Pada penerapan pembelajaran inkuiri terbimbing dan Picture and Picture jumlah kelompok 5, tiap kelompok beranggotakan 5 orang. Adanya rasa saling mengandalkan pada saat pengerjaan Iks menjadikan beberapa siswa dalam kelompok tidak ikut terlibat dalam pengerjaan soal, maka siswa cenderung mengganggu teman yang lainnya, mengerjakan tugas lain. Penataan kelas kurang tepat posisi tempat duduk telalu berdekatan sehingga siswa terlihat tidak nyaman karena harus menggeser tempat duduknya dan relatif membuat keributan.

Pada fase proses inkuiri terbimbing siswa masih terlihat kebingungan dalam menemukan sendiri dan menganalisis permasalahan sehingga membuat kelas menjadi gaduh. Hal keempat pada proses Picture and Picture siswa masih canggung dalam mempresentasikan hasil dari mengurutkan gambar menjadi urutan yang logis.

Guru masih belum bisa mengalokasi waktu sesuai dengan rpp. Menurut sayful segala pembelajaran adalah ketrampilan guru dalam menciptakan dan memelihara kondisi belajar yang optimal dan mengembalikannya bila terjadi gangguan dalam proses belajar. Dengan kata lain pengelolaan pembelajaran adalah kegiatan untuk menciptakan dan mempertahankan kondisi yang optimal bagi terjadinya proses belajar mengajar.

Pelaksanaan pembelajaran siklus 2 disusun berdasarkan refleksi siklus 1, sehingga kekurangan-kekurangan pada siklus 1 diperbaiki pada siklus 2 seperti ada perubahan pada pembelajaran inkuiri terbimbing dan picture and picture, siswa lebih teratur dan terperinci dalam memahami kegiatan yang akan dilakukan hal ini terlihat kelas lebih kondusif. Pada proses tanya jawab guru memanggil peserta didik 
yang kurang aktif untuk menjawab pertanyaan dan siswa dilibatkan dalam menyimpulkan materi dan guru meningkatkan komunikasi dengan siswa dalam pembelajaran. Pada kegiatan berikutnya diupayakan dalam pembelajaran guru lebih memperhatikan alokasi waktu yang sudah ditentukan, agar tepat waktu dan sesuai dengan rpp.

$$
\text { Kegiatan belajar inkuiri }
$$
membangkitkan suasana belajar siswa. Sasaran utama kegiatan pembelajaran inkuiri adalah (1) keterlibatan siswa secara maksimal dalam proses kegiatan belajar; (2) keterarahan kegiatan secara logis dan sistematis pada tujuan pembelajaran; dan (3) mengembangkan sikap percaya pada diri siswa tentang apa yang ditemukan dalam proses inkuiri. Kelebihan Picture and Picture diantaranya motivasi siswa dalam belajar dapat semakin berkembang. Sehingga hasil belajar akan lebih meningkat.

Hasil belajar yang harus diingat adalah perubahan perilaku secara keseluruhan bukan hanya salah satu aspek potensi kemanusiaan saja. Hasil belajar menurut bloom, mencakup kemampuan kognitif, afektif, dan psikomotorik. Pencapaian pembelajaran peserta didik (kognitif) dapat diukur dengan tes uji kompetensi, bila siswa mendapat 75 maka siswa tersebut tuntas sesuai dengan kriteria ketuntasan minimal $(\mathrm{kkm})$. Selain dengan uji kompetensi, penilaian bisa dilakukan pada saat proses kegiatan belajar mengajar berlangsung dan dari penilaian lainnya. Hasil uji kompetensi (hasil belajar siswa) dari siklus 1 sampai siklus 2 dapat dilihat pada gambar 20 .

\section{A. Hasil Belajar Kognitif}

Pelajaran IPS menggunakan metode pembelajaran inkuiri terbimbing dan picture and picture. Ketuntasan belajar yang diperoleh siswa berkaitan dengan penerapan metode inkuiri terbimbing dan picture and picture. Latihan inkuiri dapat meningkatkan pemahaman sains, produktif dalam berpikir kreatif, dan siswa menjadi terampil dalam memperoleh dan menganalisis informasi. Melalui penerapan Picture and Picture guru lebih mengetahui kemampuan tiap-tiap siswa dan motivasi siswa untuk belajar semakin berkembang. Metode pembelajaran inkuiri terbimbing dan Picture and Picture dapat meningkatkan ketuntasan belajar serta nilai rata-rata kelas siswa.

Adapun pencapaian ketuntasan belajar siswa atau kriteria ketuntasan minimal (kkm) dapat dilihat pada gambar 1 berikut.

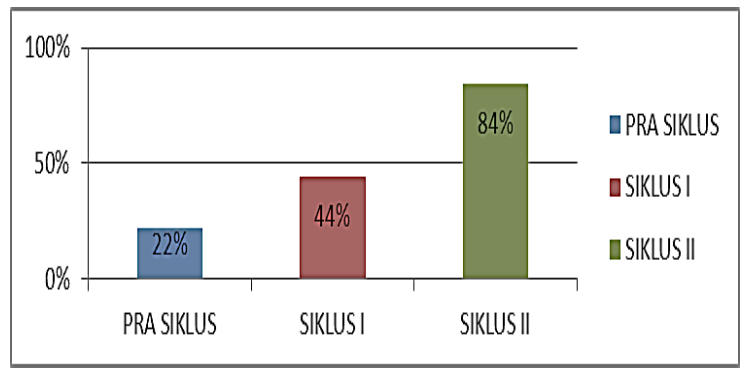

Gambar 1. Grafik Ketuntasan Belajar Siswa

Berdasarkan data yang diperoleh dari tes hasil belajar IPS, kognitif mengalami peningkatan dari setiap siklusnya. Nilai ketuntasan kognitif pada siklus1 $69 \%$ sebanyak 11 orang siswa dan pada siklus 2 $84 \%$ sebanyak 21 orang siswa dapat dilihat pada tabel 23 penelitian ini berhasil dan tidak perlu dilanjutkan lagi karena kriteria ketuntasan minimal yaitu $75 \%$ telah terlampaui.

\section{B. Hasil Belajar Afektif}

Secara keseluruhan rata-rata penilaian afektif mengalami peningkatan dari tiap siklusnya, rata-rata penilaian afektif pada 
siklus 1 mencapai rata-rata sebesar 77 (Kurang) afektif dan rata-rata afektif siklus 2 mencapai $80.36(\mathrm{~B})$, terjadinya peningkatan sebesar 3.36. Penilaian afektif berkaitan dengan teori inkuiri terbimbing dan Picture and Picture dapat melatih siswa untuk berfikir logis dan sitematis sehingga meningkatkan penilaian afektif.

Ranah afektif meliputi: menerima (accepting), partisivasi (responding), penilaian/penentuan sikap (valuing), organisasi (organization), pembentukan pola hidup (characterization by a value or value complex). Hasil belajar tidak hanya berupa nilai atau angka-angka, tetapi juga berupa perubahan tingkah laku, sikap dan mental seorang siswa. Secara keseluruhan capaian hasil belajar afektif siswa dapat dilihat pada gambar 2 berikut ini.

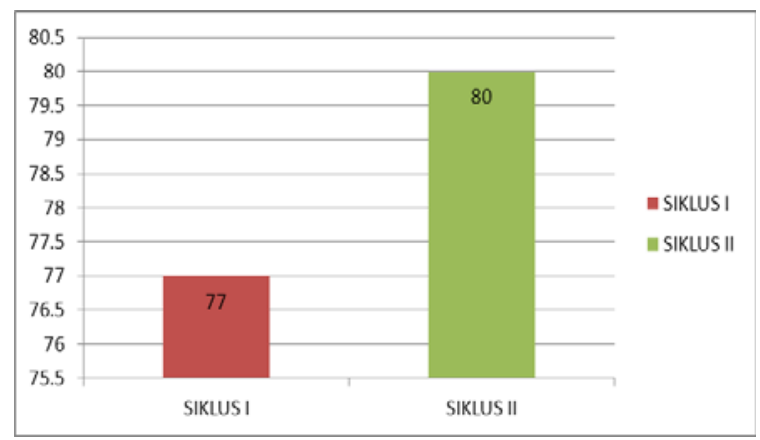

Gambar 2. Hasil Belajar Afektif Siswa

\section{Hasil Belajar Psikomotorik}

Secara keseluruhan rata-rata penilaian psikomotor mengalami peningkatan dari setiap siklusnya, dilihat dari gambar 23 ratarata penilaian psikomotor pada siklus 1 mencapai rata-rata sebesar 56 (B) dan ratarata psikomotor siklus 2 mencapai 76 (A), terjadinya peningkatan sebesar 20. Hasil belajar psikomotorik siswa secara ringkas dapat dilihat pada gambar 3 berikut ini.

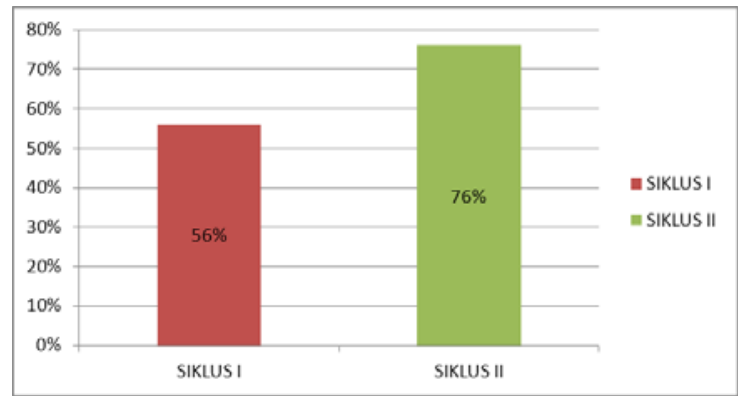

Gambar 3. Hasil Belajar Psikomotorik Siswa

Dari hasil temuan-temuan tersebut sesuai dengan pernyataan Schlenker, dalam Joyce dan Weil, menunjukan bahwa latihan inkuiri dapat meningkatkan pemahaman sains, produktif dalam berpikir kreatif, dan siswa menjadi terampil dalam memperoleh dan menganalisis informasi sedangkan Picture and Picture menarik perhatian siswa karena berupa gambar. Metode pembelajaran inkuiri terbimbing dan Picture and Picture dapat meningkatkan penilaian psikomotor.

Ranah Psikomotor (psychomotoric domain) meliputi: persepsi (perception), kesiapan (set), gerakan terbimbing (guided response), gerakan yang terbiasa (mechanical response), gerakan yang komplek (complex response), penyesuaian pola gerakan (adjustment), kreativitas (creativity). Penguasaan hasil belajar seseorang dapat dilihat dari perilakunya, baik perilaku dalam bentuk penguasaan dalam pengetahuan, keterampilan berfikir, maupun keterampilan motorik siswa.

\section{PENUTUP}

Berdasarkan hasil temuan penelitian tindakan kelas dengan pengelolaan kelas dengan metode pembelajaran inkuiri terbimbing dan Picture and Picture pada dua siklus maka dihasilkan kesimpulan sebagai berikut : 
Pertama, metode pembelajaran inkuiri terbimbing dan Picture and Picture terbukti dapat meningkatkan hasil belajar siswa dalam pelajaran IPS sesuai dengan perubahan yang bertahap pada proses pembelajaran seperti peningkatan hasil belajar siswa kognitif, afektif dan psikomotor dibandingkan pada saat refleksi awal pada siklus kedua terjadi perubahan yang signifikan. Terlihat pula dari antusiasme yang mengalami perubahan dari siklus pertama. Hal ini membuktikan bahwa guru menerapkan metode pembelajaran inkuiri terbimbing dan Picture and Picture dengan cukup baik atau dengan kata lain hasil belajar IPS dapat meningkat yang dibuktikan dengan tercapainya Kriteria Ketuntasan Minimal (KKM) 75.

Berdasarkan data yang diperoleh dari hasil belajar meliputi kognitif, afektif, dan psikomotor, siswa mengalami peningkatan dari setiap siklusnya. Prosentase ketuntasan pada siklus pertama $44 \%$ dan siklus kedua $84 \%$. Nilai rata-rata pada siklus pertama 69 dan nilai rata-rata pada siklus kedua 84.36 .Nilai rata-rata afektif siklus pertama 77 (kurang ). Nilai rata-rata afektif siklus kedua 80.36 (B). Nilai rata-rata psikomotor siklus pertama 14 (B ) dan nilai rata-rata psikomotor siklus kedua $19.12(\mathrm{~A})$.

Kedua, metode pembelajaran inkuiri terbimbing dan Picture and Picture dapat meningkatkan hasil belajar siswa. Pelaksanaan sebagai berikut : Perencanaan meliputi (1) penyusunan RPP, (2) penyiapan alat, bahan, media, dan lembar kerja siswa sesuai dengan kebutuhan. Pelaksanaan : (1) pembelajaran diawali dengan memberikan salam, tegur sapa dan mengabsen siswa. Kemudian mengaitkan pelajaran yang akan dipelajari dengan pengetahuan awal siswa. (2) penjelasan tentang metode inkuri terbimbing dan Picture and Picture, pembagian kelompok siswa secara heterogen (3) pembagian materi dan LKS kepada tiap kelompok, mempresentasikan hasil kelompok kemudian dilanjutkan kejenjang berikutnya. Evaluasi terhadap pembelajaran dilaksanakan pada proses pembelajaran dan setelah selesai pembelajaran.

Atas dasar rincian kesimpulan di atas maka dapat terjawab rumusan masalah didepan yaitu bahwa metode pembelajaran inkuiri terbimbing dan Picture and Picture terbukti dapat meningkatkan hasil belajar siswa.

\section{DAFTAR PUSTAKA}

Amri, S. (2010). Kontruksi Pengembangan Pembelajaran. Jakarta: Prestasi Pustaka

Arikunto, S. (2007). Penelitian Tindakan Kelas. Jakarta: Bumi Aksara

Dimyati \& Mujiono. (2006). Belajar dan Pembelajaran. Jakarta: PT Rineka Cipta

Djamarah, S.B.(2006). Strategi Belajar Mengajar. Jakarta: Rineka Cipta

Hamalik, O. (2006). Pendekatan Baru Strategi Belajar. Jakarta: Sinar Baru Algesindo

Hamdani. (2011). Strategi Belajar Mengajar. Bandung: Pustaka Setia

Mulyana, E. (2007). Menjadi Guru Profesional Menciptakan Pembelajaran Kreatif dan Menyenangkan. Bandung: Rosdakarya

Mulyana, E. (2003). Kurikulum Berbasis Kompetensi. Bandung: Rosdakarya

Richards, J.C. (2001). Curriculum Development in Language Teaching. Cambridge University Press

Rohani, A. (2004). Pengelolaan Pengajaran. Jakarta: Rineka Cipta.

Sadirman. (2007). Model-Model Pembelajaran. Jakarta: Rajagrafindo Persada

Sapriya., Sundawa, D \& Masyitoh, L. (2006). Pembelajaran dan Evaluasi Hasil belajar IPS. Bandung: UPI.

Sudrajat,H. (2001). Implementasi KBK. Bandung: PT Cipta Rieka Grafika

Sujana, N. (2010). Penilaian Hasil Proses Belajar Mengajar. Bandung: PT Remaja Rosdakarya 
Sumardi. (2007). Profesi Kependidikan. Bogor: FKIP UNPAK

Supriono, A. (2010). Cooperative Learning Teori dan Aplikasi Paikem. Yogyakarta: Pustaka Pelajar

Suryabrata, S. (2010). Psikologi Pendidikan. Jakarta: Rajawali Pers

Sutardi, D \& Sudirjo, E. (2007). Pembaharuan dalam $P B M$ di SD. Bandung: UPI PERSS

Sutikno, M.B. (2007). Menggagas Pembelajaran Efektif dan Bermakna. Jakarta: NTP Press Mataram

Syah, M. (2000). Psikologi Pendidikan dengan Pendekatan Baru. Bandung: PT Remaja Rosdakarya,

Wiraatmadja, R. (2009). Metode Penelitian Tindakan Kelas. Bandung: Remaja Rosda Karya

Woolfolk, A. (2009). Educational Psychologi active Learning. Yogyakarta: Pustaka Pelajar

Yufiarti. (2009). Psikologi Pendidikan dan Penerapannya. Jakarta: Pusat Pengembangan Kemampuan Manusia 